\title{
Tělesnost svobody v raném díle Simone de Beauvoir
}

\section{Bodily Freedom in Early Writings of Simone de Beauvoir}

\author{
Daniel Štěpánek
}

\begin{abstract}
Abstrakt
Podoba francouzské filosofie druhé poloviny 20. století je silně ovlivněna způsoby konceptualizace úlohy těla během vnímání. Tělesnost, která pro vědomí zprostředkovává prožitky, utváří veškeré vztahy člověka k druhým. V díle Simone de Beauvoir je třeba chápat svobodu jako podmíněnou specifickým zpưsobem prožívání těla člověkem. Cílem tohoto příspěvku je ožrejmit povahu této specifičnosti. Naším výchozím zdrojem k dosažení stanoveného cíle je první novela Beauvoir, Pozvaná (L'Invitée), kde je v dialozích jednotlivých postav možné nahlédnout nejen povahu specifického zpưsobu prožívání těla, ale i povahu svobody, která je tímto způsobem podmíněna.
\end{abstract}

\section{Klíčová slova}

Beauvoir, fenomenologie, svoboda, perspektivita, tělesnost

\begin{abstract}
What is being analyzed and subsequently interpreted in our study, is Simone de Beauvoir's conception of freedom and its bodily determination. Because we are using Beauvoir's first novel, She Came to Stay (L'Invitée), where her first conceptualization of these fenomenons can be found. Although this novel is strongly based on dialogues between three main characters, we are convinced, that it is precisely their dialogue, what allows specificity of Beauvoir's conceptions. Therefore, by interpreting some of these dialogues we are trying to make clear, where according to Beauvoir freedom begins and how it is being limited.
\end{abstract}

Text je upravenou částí diplomové práce Kořeny existenciální fenomenologie Simone de Beauvoir, která byla v roce 2016 obhájena na Fakultě humanitních studií Univerzity Karlovy. 


\section{Keywords}

Beauvoir, phenomenology, freedom, perspectivity, body

\section{Úvod}

Způsob myšlení, který je vlastní Simone de Beauvoir, nemůže být definován prostřednictvím některého $\mathrm{z}$ „ready-made“ směrů, kterými bychom mohli uzavřít její dílo do konkrétních, tomu kterému vybranému směru odpovídajících kategorií, jimiž by bylo možné dojít k porozumění šířky a hloubky jejích myšlenek a jejich následné artikulaci. ${ }^{1}$

Záměrem předkládané stati je podat možný výklad těch aspektů raného díla Simone de Beauvoir, které tvoři ústřední charakter existenciální fenomenologie - metodického př́stupu, kterým dle současných interpretací tvořila. Myšlenkovým východiskem nám bude blízkost Pozvané k ústřednímu dílu blízkého př́tele Beauvoir, Maurice Merleau-Pontyho, v jehož Fenomenologii vnimání je, dle našeho názoru, možno narazit na množství styčných bodů, jak lze přistupovat k možným intencím prvotních myšlenkových konceptualizací problematiky vztahu k druhému v rozměru tělesnosti.

Pozvaná je novelou, na které Beauvoir pracovala více než čtyři roky a kterou publikovala v roce 1943. Na třech hlavních postavách - Františce, Xavieře a Petrovi -Beauvoir ilustruje vztah Jean-Paula Sartra s Olgou a Wandou Kosakiewiczovými. Františka má představovat ženu, která je ve vztahu spoutaná svým partnerem Petrem do takové míry, že veškeré aspekty její existence se odvíjejí pouze z tohoto vztahu. Nedokáže o sobě samé rozhodovat, a proto vše, co dělá, dělá pouze v mezích svého vztahu s Petrem. Petr si uvědomuje, že Františka je na něm závislá, bere ji jako samožrejmou, vždy přítomnou a nikdy mu v ničem neodporující osobu. Petr toho využije ve chvíli, kdy se seznámí s Xavierou, dívkou, která žije nespoutaně, bezhlavě, uzavřena v oka-

1 Dvojice předních „beauvoirovských“ badatelů, Kate a Edward Fullbrookovi, poukazují na odmítání předpojatosti danými způsoby př́ístupu ke světu, jaké je vlastní Beauvoir: „Platnost vědeckého zákona je založena na sérii experimentů, které ho etablují a následně shrnují. Beauvoir trvá na tom, že podobným způsobem je soubor jednotlivých zkušeností, prověřovaný filosofem-novelistou a/nebo esejistou, jediným legitimním základem pro metafyzickou pravdu. Navíc, stejně jako eticky př́ísné vědy pokračují v konfrontaci etablovaných zákonů prostřednictvím nových a sofistikovanějších empirických dat, i filosof musí nadále srovnávat svá obecná filosofická tvrzení s výsledky nových aplikací na konkrétní existenci." Viz Kate Fullbrook - Edward Fullbrook, Simone de Beauvoir: A Critical Introduction, Cambridge: Polity 2008, s. 42. (Překlady anglických úryvků pořídil autor.) 
mžiku, ve kterém se právě nachází, aniž by brala ohled na svou budoucnost a minulost. Petrův narůstající zájem o Xavieru stále více narušuje Františčinu partnerskou optiku, což postupně vede k rozrušení jejího dřívějšího zpơsobu sebereflexe. Rozrušováním partnerské sebereflexe je Františka nucena konfrontovat samu sebe, to, kým je, s tím, kým být může. Postupně si začíná uvědomovat svou svobodu, kterou si dříve uvědomovala pouze ve chvílích osamoceného prožívání prostředí, v němž se nacházela.

Beauvoir v hlavních povahových obrysech jednotlivých postav vychází ze Sartrova pojetí vztahu k Druhému, představeného v díle Byti a nicota. Františčin původní postoj k Petrovi je postojem masochistickým, zatímco Petrův postoj k Františce je postojem sadistickým. Těmito ilustracemi chce Beauvoir následně ukázat způsob, jakým je možné překonat Sartrovo pojetí. Prostředníkem, kterým o toto překonání Beauvoir usiluje, je Gerbert, vedlejší postava novely, k němuž se Františčin vztah proměňuje v důsledku změn, jakými prochází její vnímá sama sebe v rámci vztahu s Petrem. V Gerbertově sebereflexi a z ní vycházejících vztahů k druhým lidem vychází najevo postoj, který Beauvoir zastává vưči Merleau-Pontyho pojetí tělesnosti - postoj, kterým je umožněno koncipovat pozitivní, svobodou prostoupený přístup k Druhému.

\section{Situovanost}

V 1. části Pozvané je zřetelně znát přístup k tělesnosti jakožto prvotnímu zdroji smyslu. Podíváme-li se totiž na Františčin popis vlastních prožitků těsně po probuzení, můžeme celkem jasně vidět důraz, jaký je kladen na tělo a tělesnou spjatost se světem: „V tuto dobu už nebývalo v divadle živáčka, ale dnešní noci žilo, psací stroj klapal, lampa rozlévala na papíry růžové světlo. A já jsem tady, moje srdce bije. Dnes v noci má divadlo srdce, které bije."2 Předtím vnímala Gerberta, druhého člověka v divadle, přesto dává při popisu okolí přednost svému tělesnému prožívání, tedy pocitování prostřednictvím těla, jež Františka může prožívat a skrze které je spojena se světem. ${ }^{3}$

2 Simone de Beauvoir, Pozvaná, přel. Jiří a Libuše Konůpkovi, Praha: Melantrich 1991, s. 7.

3 „Novela začíná tím, že se Františka (jejíchž metafyzických reflexí jsme svědky) chová jako zkušenostní zástupce pro dva filosofické nedostatky či mýty, které jsou vlastní západní filosofii: neexistuje žádný př́mý vztah mezi individuálními vědomími, a s vědomím může být zacházeno jako s nezávislým na těle. Beauvoir vidí zkušenost Druhého a vtělenost vědomí jako spojené, a proto oboje jako vztažené k rozlišení imanence a transcendence v lidské zkušenosti." Viz Edward Fullbrook, She Came to Stay and Being and Nothingness, Hypatia: A Journal of Feminist Philosophy 14, 1999, č. 4, s. 50-69: 56. 
Právě tímto popisem Františčina soustředění se na své tělesné prožitky se pozice Beauvoir přibližuje Merleau-Pontyho pojetí tělesného prostředkování vnějšího, jak se asi nejexplicitněji ukazuje v užití metafory bijícího srdce, náležejícího ve Františčině popisu divadlu, které je tak projekcí vlastního tělesného prožívání. Tuto metaforu totiž ve Fenomenologii vnimáni užívá i Merleau-Ponty: „Vlastní tělo je ve světě, podobně jako je srdce v organismu: neustále udržuje naživu podívanou, na niž lze patřit, zevnitř ji uvádí do chodu a živí, tvoři s ní jeden systém. “" Dle tohoto popisu se tělo vynachází „ve světě“, nikoli „na světě“, jak říká Merleau-Ponty. Domníváme se, že důvodem pro toto odlišení, jež zde činíme, je rozdíl v působení světa na tělo, a naopak. Pokud by totiž bylo tělo na světě, leželo by na něm jako předmět, který se na něm pouze nachází, aniž by s ním mělo jako předmět co do činění. Naproti tomu tělo, které je ve světě, napovídá, že je součástí světa - je s ním propojeno a tak umožňuje i pronikání světa do sebe stejně jako sebe do světa. Co je důležitější, svět je v Merleau-Pontyho popisu chápán jako organismus, to znamená jako něco živého, co má vlastní život, mění se a vyvíjí. Pojmeme-li proto tělo jako srdce, náležející takovému organismu, je tělo tím, co udržuje svět naživu. Z hlediska námi zkoumaného je tím vyjádřeno prostředkování světa tělem jakožto zprostředkovatelem vnějšího. To znamená, že prožitky těla, které člověk pocituje, jsou jen součástí světa, výkrojem světa v okruhu vynacházení se těla.

Tělo jako prostředek vnímání věcí v okolí, prožívání jejich působení na vědomí člověka, je i prostředníkem mezi jeho sebereflexí a vybavováním a přiznáváním významů vnímaných a prožívaných věcí v jeho okolí. ${ }^{5}$ Tělesný rozměr vnímání tak umožňuje člověku zvýznamňovat vnímané věci jakožto své a tím

4 Maurice Merleau-Ponty, Fenomenologie vnimáni, přel. Jakub Čapek, Praha: OIKOYMENH 2013, s. 255.

5 V tomto smyslu sdílíme názor s Anne Morgan, která ve své studii tvrdí: „Mezi reflexemi zjištuji, že já jako lidské vědomí jsem neoddělitelně spojen s bytím. Mám tělo, které se vyjevuje jako vyjádření mého vztahu ke světu. Toto tělo je pro Beauvoir historickou ideou či faktickou situací. Avšak co Beauvoir míní historickou, faktickou situací? Za prvé, zjištuji, že jsem maso a krev, potřebuji jídlo, vodu a další fyzické nezbytnosti. Jsem fyzickým předmětem, který může být rozdrcen, a tělem, které se bude rozpadat a zemře. Za druhé, ačkoli jako člověk nevytvářím svět [...] nacházím sám sebe situovaného spolu s dalšími lidmi ve světě, kde jsou předměty již prodchnuté lidskými významy. Druzí existovali přede mnou a jiní právě existují se mnou. Projektovali a nadále i pokračují v projektování společenských, kulturních, ekonomických a symbolických systémů, ve zkratce historickou situaci, kterou nyní odkrývám prostřednictvím mého vědomí." Viz Anne Morgan, Simone de Beauvoirs Ethics of Freedom and Absolute Evil, Hypatia: A Journal of Feminist Philosophy 23, 2008, č. 4, s. 75-89: 77. 
z nich i činit nástroje. „Netoužila ani tolik po whisky, spíše ji přitahovaly černé chodby. Když v nich nestála, pak vůně prachu, pološero a zoufalá opuštěnost neexistovaly pro nikoho, vůbec neexistovaly. Ale ted' tu byla. Červeň běhounu prorážela přítmím jako nějaká nesmělá lampička. Františka měla tu zvláštní moc, že svou přítomností vytrhávala věci z jejich neuvědomění, dodávala jim barvu a vůni. Sešla o patro níže a strčila do dveří vedoucích do sálu. Jako by jí bylo svěřeno nějaké poslání, musela přimět k existenci ten pustý sál plný noci. Železná opona byla spuštěna, zdi byly cítit čerstvým nátěrem. Křesla z červeného plyše byla seřazena, netečná, v očekávání. Před chvilkou ještě křesla nečekala na nic. Ale ted' tu byla ona a křesla k ní natahovala svá opěradla." ${ }^{* 6}$ Františčino procházení se po nočních prostorách divadla ukazuje ve způsobu, jakým se Františka sama chápe všeho, co se okolo ní nachází a co míjí, na způsob, jakým se k těmto jednotlivým věcem staví. Takový způsob stavění se k věcem musí mít dvojí charakter: jednak je zapotřebí, aby se jím vnímající otevíral, resp. aby byl otevřen možnosti působení oněch věcí na sebe, a jednak musí být působení těchto věcí uchopeno vnímajícím určitým způsobem, jímž bude toto působení konkretizováno do podoby určitého významu. ${ }^{7}$

Pro subtilnější porozumění tomu, co se zde pokoušíme vyjádřit, využijme opět Merleau-Pontyho úvah: „Subjekt počitku není ani myslitel, který zaznamenává určitou kvalitu, ani netečné prostředí, které je kvalitou zasaženo či pozměněno, nýbrž určitou potencí, jež se rodí spolu s jistým existenčním prostředím či se s ním synchronizuje."8 Merleau-Pontyho pojetí zde vyjadřuje, že člověk je prostřednictvím prožitků svého tělesného sepětí s okolním světem, tedy svou určitým způsobem zvýznamněnou tělesností, současně i konkretizátorem sebe samého.

$6 \quad$ S. de Beauvoir, Pozvaná..., s. 8.

7 Podobným směrem výkladu jde opět i Anne Morgan: „Člověk má tělo, které je místem a způsobem střetnutí s jeho faktickou situací. Co je faktickou situací? Z pohledu Beauvoir fakticita sama zahrnuje naše fyzická já (physical selves), hrubé materiály, které používáme $\mathrm{k}$ tvorbě předmětů, tyto předměty samy, označení, která přisuzujeme předmětům, jiným označením, ne-lidským zviŕatům a sobě navzájem. Patří do ní i sociální, kulturní, symbolické, politické a ekonomické systémy, uvnitř kterých existujeme. Fakticita je vše, co ovlivňuje lidský život, včetně materiálních a nemateriálních vedlejších produktů vědomí (sama je však odlišná od vědomí). Proto je tělo jako faktická situace způsobem, ve kterém je člověk zasazený (embedded) uvnitř fakticity.“ Viz Anne Morgan, Simone de Beauvoirs Ethics, the Master/Slave Dialectic, and Eichmann as a Sub-Man, Hypatia: A Journal of Feminist Philosophy 24, 2009, č. 2, s. 39-53: 42.

M. Merleau-Ponty, Fenomenologie vnimání.., s. 265. 
Nelze tomu však rozumět tak, že by člověk byl jen pasivním „přijímačem“ vnějších signálů, kterým pouze dává některý z předem připravených významů. Tělesnosti člověka je třeba rozumět spíše jako prostředí, které se na jedné straně přizpůsobuje vnímanému, aby na druhé straně mohlo v co nejhlubši širri a plnosti svého působení splynout s tělesností, která je vnímá. Jelikož však není možné, aby se věci samy přizpůsobovaly člověku konkrétním způsobem se v jejich okolí vynacházejícímu, musí se člověk přizpůsobovat jim stejně jako přizpůsobovat si je. Svět totiž není souborem významů, které může člověk rozumově odkrývat a tím ho v jeho jednoduchosti i sumarizovat. Významnost každé věci náleží tomu, kdo tuto věc vnímá, avšak význam, jaký vnímající této věci přisoudí, záleží na způsobu, jakým k ní přistoupí. Každý takový způsob zvýznamňování okolí je tak vyjádřením postoje zvýznamňujícího člověka samého. A jen dodejme, že ne každý postoj dává vnímajícímu stejné možnosti zvýznamňovat své okolí. Či slovy Merleau-Pontyho: „Je třeba, abych nalezl postoj, který vnímanému teprve poskytne prostředek, aby se blíže určilo a stalo něčím..."9

Okruh vynacházení se těla je ve své podstatě oblastí, do níž může tělo aktivně zasahovat a v níž může člověk reagovat na prožitky, kterými ho tato oblast prostřednictvím jeho těla oslovuje. Každým svým prožitkem je prožívající vedený $\mathrm{k}$ artikulaci prožívaného, aby mohl nejen reflexivně uchopit prožívané, ale především porozumět způsobu, jakým je vlivem symbiotického vztahu těla a světa, prostř̌edkovaného tělesnými prožitky, situovaný ve světě. ${ }^{10}$

Určitý konkrétní způsob situovanosti člověka ve světě ovlivňuje způsob, jakým se vše takto situovanému člověku dává. ${ }^{11}$ Když Františka popisuje, jak na ni divadlo v noci působí, přibližuje tím zároveň atmosféru, jaká v divadle

9 Tamtéž, s. 268.

10 Touto cestou jde ve svém výkladu i Edward Fullbrook: „Situační povaha fikce umožňuje ukázat, jakým způsobem je tělo spjato se svými orgány vnímání a subjekt se svým vědomím. Tělo jako subjektivní a subjekt jako vtělený. Ve skutečném světě se předměty odhalují pouze pro vědomí, která jsou individuálně a materiálně situovaná. Vněmy jsou podmíněny variacemi povahy vtělení člověka a strukturovány př́iběhy, které se říkají a poslouchají o jeho minulosti a budoucnosti.“ E. Fullbrook, She Came..., s. 57.

11 Eva Gothlin argumentuje podobně: „Beauvoir nevidí tělo jako něco opanovaného vědomím či jako něco, co je podřízeno vědomí. V Druhém pohlaví tvrdí, že tělo ,je situací a člověk ,dějinnou ideou', takže biologická povaha lidí není nikdy zakoušena z druhé, sociální povahy [...] Beauvoir zdůrazňuje rozdíly mezi pohlavími, ale současně i to, že význam těchto rozdílů je vždy závislý na historické situaci a na výkladech těchto situací." Viz Eva Gothlin, Simone de Beauvoirs Notions of Appeal, Desire, and Ambiguity and their Relationship to Jean-Paul Sartres Notions of Appeal and Desire, Hypatia: A Journal of Feminist Philosophy 14, 1999, č. 4, s. 83-95: 84. 
panuje. Avšak tato atmosféra není něčím samostatně existujícím nebo náležejícím divadlu jako něco jemu vlastního. Atmosféra prázdnoty, již Františka v nočním divadle popisuje, je popisem jejího vlastního prožívání vlastní tělesné situovanosti. Proto i to, že se Františce zdá divadlo v jí popisované noci „živé“, znamená, že mu sama Františka přisuzuje život. Veškeré předměty, které v této atmosféře vlastního prožívání svého okolí Františka vnímá, poukazují na způsob, jak je Františka v danou chvíli reflektivně artikuluje. Pro přesnější pochopení toho, oč nám v tomto zdlouhavém výkladu jde, využijme Merleau-Pontyho: „...nedokážu uchopit jednotu předmětu bez zprostředkování, jímž je tělesná zkušenost [...] já mohu dospět k předmětu nikoli proto, že jej zevnitř konstituuji, nýbrž proto, že se perceptivní zkušeností nořím do tlouštky světa. "12 Jako perceptivní zkušenosti, jimiž Merleau-Ponty označuje způsob, kterým jsou tělesné prožitky vnějšího konkretizovány určitým způsobem, ovlivněným právě prožívaným rozpoložením, tak můžeme rozumět způsobu, jakým si Františka vykládá věci nacházející se v jejím okolí. Způsob jejich vzájemné vázanosti, kterou jim Františka přisuzuje, je dán způsobem, jakým je Františka může vnímat.

Tím se dostáváme k tomu, že zpo̊sob, kterým Františka jednotlivé předměty popisuje, vypovídá o povaze rozpoložení, ve kterém se právě nachází. Absence jiných lidí, které si Františka všímá jako první, umožňuje soustředit se více na věci, které ji obklopují. Noční osamoceností může zřetelněji vnímat jednotlivé aspekty věcí, kterými je přiváděna ke zřetelnějšímu vnímání sebe samé, svého prožívání, a v konečném důsledku i svého rozpoložení. „V té chvíli nelitovala, že Petr není u ní, protože byly radosti, které v jeho přítomnosti nemohla poznat: všechny radosti samoty. Ztratila je už před osmi léty a občas nad tím pocitovala cosi jako výčitku. Svezla se na tvrdé dřevo lavičky. Na asfaltovém chodníku zazněl rychlý krok. Ulicí projelo nákladní auto. Byl tu hluk pohybu, nebe, váhavého listí stromů, růžová okenice v černé fasádě. Ale nebylo už Františky. Nikdo už nikde neexistoval."13 Tento detailní popis můžeme chápat jako popis jejího rozpoložení, k němuž dochází prostřednictvím koncentrace na prožitky věcí, jež se nacházejí ve Františčině okolí. Uchopíme-li osamocenost, která Františku vedla k této koncentraci, pomocí které postupně dospěla až ke koncentraci na sebe samu, vidíme, že pro sebe už ona sama neexistuje. Kvưli tomuto stavu osamocenosti si Františka zřetelně

12 M. Merleau-Ponty, Fenomenologie vnimáni..., s. 198.

13 S. de Beauvoir, Pozvaná..., s. 124. 
uvědomuje svou vlastní prázdnotu. Františčina vlastní tělesná situovanost ji tedy vede $\mathrm{k}$ uvědomění si vlastní neexistence.

Prostřednictvím rozvinutí Františčiných popisů z merleau-pontyovského pohledu je patrné, že Beauvoir přijímá daný pohled na tělo coby prostředníka mezi vědomím a vnějším světem, přičemž jsou to právě prožitky tohoto tělesného sepětí, tělesnost vědomí, co vědomí umožňuje přizpůsobovat si vnější vzhledem $\mathrm{k}$ právě prožívanému vnitřnímu a zároveň vnějšímu působit na toto vědomí a vybízet ho k přizpůsobení. Proto prožitky tělesné zkušenosti, tyto perceptivní zkušenosti upomínají prožívajícího na jeho vlastní tělesnou situovanost, na to, kým prožívající „ve světě“ je.

\section{Perspektivita}

Každé tělo je sobě vlastní perspektivitou, upomínkou určité determinovanosti tělesnosti, resp. tělesných prožitků, kterými se prožívajícímu dávají věci a svět, k němuž tělesně prožívající náleží. Právě jakožto takováto součást světa, jež je v perspektivním smyslu zkonkretizovaná, je tělesnost člověka i omezením toho, co tento člověk může ve světě prožívat a co z něj může vnímat.

Perspektivita těla sice není odstranitelná, nicméně pozměnitelná a proměnitelná je: „Dřív jsem bývala zoufalá, když jsem si představila, že nepoznám nikdy víc než malý kousek světa [...] Já jsem ted' klidná, protože jsem dospěla k přesvědčení, že at̉ jdu kamkoliv, ostatní svět se přemistuje se mnou. A to mě zachraňuje před jakýmkoliv pocitem lítosti. (,Lítosti nad čím?‘) Že bydlím jenom ve své kůži, když je země tak ohromná. "14 Beauvoir těmito Františčinými slovy dává vcelku jasně najevo, že tělo člověka je zprostředkovatelem světa, „přizpůsobovačem“ okolí člověka a tím i spolutvưrcem prostředí, v němž je tento člověk „doma“. Františčino prožívání vlastního tělesného sepětí se světem ukazuje na proměnu, jíž v rámci svého postoje ke světu prošla. Jak sama říká, nejprve se soustředila na poznávání a tím i zvýznamňování toho, co se jí v jejím okolí zrovna namanulo. Časem však došla k uvědomění, že toto poznání je samou svou povahou omezené, totiž že poznávání je založeno na zvýznamňování tělesných prožitků, které jsou v poznávajícím jakožto vnímajícím probuzeny způsobem jeho vynacházení se ve světě. A právě uvědomění si tohoto způsobu vynacházení se ve světě jakožto způsobu možné konkretizace světa vyvolalo ve Františce takovou úzkost z možnosti vlastního determinovaného omezení zvýznamňování, že změnila postoj v určitou for-

14 S. de Beauvoir, Pozvaná..., s. 11. 
mu smírrlivosti s vlastní tělesnou perspektivitou, díky níž přistupuje ke svému tělu a jeho prožitkům jako $\mathrm{k}$ tomu, nač se má v poznávání vnějšího primárně orientovat. $^{15}$

Tělesnost prostředkuje věci pouze $\mathrm{z}$ perspektivy a tato perspektiva je pouze mou. To také vede $\mathrm{k}$ uvědomění si, že druhý má vlastní perspektivu díky svému tělu, a proto i jeho tělesnost podává stejné věci z jemu vlastní perspektivy, dokonce i z takové, která může být (a po většinou i je) naprosto odlišná od mé: „Pochopila jsem, že se člověk musí smířit s tím, že si nelze vybírat [...] Zpočátku mě to stálo odříkání, ale ted' mi to není líto, protože věci neexistují pro mne, a zdá se mi, že vůbec neexistují [...] Cítila, že je to moc silné. Chodby, sál, jeviště přece nezmizely, když za nimi zavřela dveře. Ale existovaly už jen za dveřmi, na dálku. " 16

Františka se postupně k pochopení této své perspektivity dobírá tak, že věci a svět vnímá jako své vlastní: „Jen ona sama vybavovala smysl z těch opuštěných míst, z těch spících předmětů. Byla tam a ony jí patřily. Svět jí patřil. “17 V tomto popisu vlastnění světa jako něčeho Františce vlastního se skrývá právě ono uchopení světa jako něčeho daného vlastní perspektivitou, na čem pak spočívá i ovýznamnění věcí, které se v prostředí tělesného vynacházení se vyskytují. „Vybavování smyslu“ z věcí, o kterém Františka hovoří, je popisem právě tohoto rozměru téměř automatického ovýznamňování věcí jakožto Františčině tělesné perspektivitě náležejících předmětů. ${ }^{18}$

Perspektivita vědomí, ovlivňovaná tělesností každého člověka, však není podmíněná ve své konkretizaci pouze tímto tělesným vyskytováním se, prostřednictvím něhož se „uvlastňuji“ všechny věci nacházející se v prostředí tělesnosti coby mé předměty, nýbrž je současně podmíněná i proměnlivostí

15 „Kdybych tedy chtěl přesně vyjádřit perceptivní zkušenost, měl bych říci, že takhle se to ve mně vnímá, nikoli, že já vnímám. Každý počitek v sobě nese zárodek snu či odosobnění, jak to zakoušíme v tom zvláštním omámení, do něhož nás počitek uvrhne tehdy, když se naše prožívání odehrává opravdu na jeho úrovni." M. Merleau-Ponty, Fenomenologie vnímáni..., s. 270.

16 S. de Beauvoir, Pozvaná..., s. 12.

17 Tamtéž, s. 8.

18 „Skrze počitek uchopuji na okraji svého osobního života a svých vlastních aktů život vědomí jako danost, z níž povstávají, uchopují život svých očí, svých rukou, svých uší jako jednotlivá přirozená Já. Pokaždé když zakouším nějaký počitek, zakouším, že se týká nikoli mého vlastního bytí, totiž bytí, za něž jsem zodpovědný a o němž rozhoduji, nýbrž nějakého jiného já, které se již rozhodlo pro svět, které se již otevřelo některým z jeho aspektů a synchronizovalo se s nimi. Mezi mým počitkem a mnou se nachází mocná vrstva původně nabytého vědění, jež znemožňuje, aby má zkušenost byla sobě samé zřejmá.“ M. Merleau-Ponty, Fenomenologie vnímání..., s. 270. 
každého prožitku, které tělesné spojení se světem a s věcmi v něm se nacházejícími vyvolává. $\mathrm{Z}$ toho důvodu je perspektivita tělesnosti neustále se proměňující a tím i neustále nás bombardující novými a jinými významy. Každý člověk, rozumějící sám sobě na základě svého tělesného spojení se světem, resp. na základě významů, jimiž se vztahuje $\mathrm{k}$ věcem jakožto předmětům, jejichž prostřednictvím uchopuje svou vlastní existenci, je tak neustále stavěn před nutnost vypořádávat se $\mathrm{s}$ určitou mírou vlastní proměnlivosti. ${ }^{19}$

Na zde citovaných pasážích z první kapitoly Pozvané se také ukazuje, do jaké míry Beauvoir přikládá tělesnosti důležitost. Vnímání, umožněné momentální situovaností těla do konkrétního prostředí, se ukazuje být zdrojem aspektů věcí, tj. tělesně vnímatelných, a proto i určitým konkrétním způsobem identifikovatelných vlastností.

Pro porozumění dosahu, jaký tento závěr má, dejme ho do hlubší souvislosti s Merleau-Pontyho popisem vnímání, náležejícího tělesné situovanosti. Vnímání, kterým se mi dává svět jakožto oblast mé možné tělesné aktivity, je podmíněno schopností těla dávat svět - a to jak svět již dopředu existující, tak svět, který si svou tělesnou situovaností jako takový vytvářím. Schopnost těla každého člověka jakožto v tělesnost uzavřené existence je schopností utvářet vnímání vnějšího v podobě určité perspektivy, která je každému jednotlivci vlastní.

Uvědomovat si určitý předmět, jenž se nachází v oblasti mé tělesné situovanosti jako tělo, jemuž náleží vědomí podobně jako mně, to znamená uvědomovat si určitý předmět jako tělesně se v oblasti mého jednání vynacházející existenci, vưči níž jsem schopný zaujmout konkrétní postoj, předpokládá, že se v reflexivním obratu vlastního vědomí vztahuji sám k sobě jako k bytí pro sebe. Být bytím pro sebe, kterému náleží tělo, resp. být tělesně situovaným vědomím, umožňuje vnímat jiný předmět jako tělo, kterému také náleží vědomí - vnímat toto tělo jako druhého.

Důležitost těla a tělesné situovanosti ve světě, kterou klade Merleau-Ponty na vztah k druhému jako na vztah k vědomí, se hluboce odlišuje od způsobu, jakým se konstituuje vztah k druhému v Hegelově pojetí. Oproti stanovení objektivních kritérií, na základě nichž se můžeme s druhým vztahovat k sobě navzájem, jak to činí Hegel svým konceptem mravnosti v Základech filosofie práva, je třeba věnovat pozornost vlastní perspektivitě, utvářené mou těles-

19 „Každý počitek je přísně vzato první, poslední, a jediný svého druhu, a tedy je zrozením a smrtí. Subjekt, který jej zakouší, začíná a končí s ním.“ Tamtéž. 
ností jakožto „subjektivním“ zakoušením toho, co se nachází v oblasti mé reflexivity okolního.

\section{Svoboda}

Chceme-li porozumět důvodům, pro které je námi zkoumaná novela zakončena způsobem na první pohled tragickým, je třeba nejprve porozumět způsobu, jakým Beauvoir nastiňuje, co rozumí pod popisy toho jednání, které označuje za svobodné, stejně jako pod vyjádřeními o svobodném charakteru těch druhých, s nimiž nechává Františku se stýkat. My sami věříme, že postava Gerberta je v rámci existenčního vývoje Františky nezbytným předpokladem, především pro proměňující se vnímání, kterým se Františce postupně ukazuje Gerbert. Přejdeme-li rovnou k dle našeho názoru nejdůležitějšímu popisu Františčina reflektování Gerberta, domníváme se, že spatříme jasné, přestože implicitní pojetí svobody Beauvoir: „Přepadla ji ted' úzkost. Byl tu před ní sám, bez závazků, naprosto volný. Jeho mládí, úcta, kterou choval vždycky k Petrovi i k ní, nedovolovaly očekávat, že by sám něco podnikl. Jestli chtěla, aby se něco přihodilo, pak mohla Františka počítat jen sama se sebou. “ ${ }^{20} \mathrm{~V}$ tomto můžeme spatřit dva aspekty pojetí svobody u Beauvoir.

Za prvé, svobodným je pouze ten člověk, který je ochotný čelit samotě, tzn. takový člověk, který je schopný nezavazovat svou existenci prostřednictvím koexistence $\mathrm{v}$ rámci partnerské vzájemnosti, jíž by určil svou identitu hranicemi sebereflexivního vynacházení se ve světě. Gerbert, na němž je tento aspekt ilustrován, je právě takovým - absencí závazků, schopností „být sám“, náleží jeho existenční situovanosti volnost v realizaci sebe sama.

Za druhé, svobodnému člověku schopnému existenční samostatnosti jsou hranicemi realizace jím rozvrženého jednání druzí. Tím nechceme říci, že by se lidé navzájem omezovali již jen tím, že se nacházejí ve sdíleném prostředí, nýbrž chceme vyjádřit, že existenční situovanost, charakteristická perspektivitou danou tělesnou situovaností, podává druhého jako konkrétním způsobem svého existování schopného konkrétního způsobu vzájemnosti. Proto je svobodnému člověku dán reflexivní odstup vůči v konkrétním okamžiku se dávajícímu vyjadřování identity existenční situovanosti druhého. Tímto způsobem je umožněno nejen porozumět tomu, kým druhý je, ale také i zaujímat odpovídající postoj vůči druhému, který se svou tělesnou situovaností v konkrétním okamžiku vyjadřuje konkrétním způsobem. Tímto postojem by

20 S. de Beauvoir, Pozvaná..., s. 374. 
svobodný člověk byl schopen jak uchovat si svou svobodu, tak respektovat možnost druhého být svobodným ve svém existování.

Náš výklad dvou aspektů svobody se zdá být podpořen i vyjádřením samotného Gerberta ohledně upřednostňování přátelství před láskou: „Jsou ale jiné vztahy stejně hluboké jako láska [...] Já kladu přátelství mnohem výše. Já bych si velmi dobře zvykl na život, v němž by bylo jen přátelství. " 21 Nejenže přátelství je stejně hlubokým vztahem jako láska, ale dokonce, jelikož není na partnerské vzájemnosti založeným způsobem vztahu k druhému, umožňuje respektovat individualitu každého jakožto jednotlivce, jemuž náleží vlastní perspektiva stejně jako nárok na to mít perspektivu odlišnou. Všimněme si totiž, že při svém popisu Gerbert hovoří v první osobě, využívaje vyjádření jako ,já kladu“, ,já bych si zvykl“ apod. Jako svobodný člověk dává těmito vyjádřeními najevo, že sice zastává toto konkrétní stanovisko, avšak že respektuje i stanovisko odlišné, vlastní jinému člověku.

Oba aspekty, jaké se domníváme spatřovat ve Františčině popisu Gerbertova charakteru, jsou výrazem postupujícího osamostatňování se Františky samotné. Zatímco na počátku novely se dívala na Gerberta prostřednictvím Petrovy perspektivy, vidíce ho jako mladého, naivního, nerozhodného a proto nesamostatného mladíka, vidí ho poté, co partnerská vzájemnost panující mezi ní a Petrem postupně ochabovala - a to až do nynějšího momentu -, jako člověka ryze individuálního, nezávislého na jakémkoli typu vzájemnosti, jež by nutila převzít partnerskou identitu s její vlastní perspektivou.

Gerbertův důraz na přátelství - vztah, díky němuž je možné nejryzeji vyjádřit respekt vưči individualitě druhého - je výrazem svobody vzájemnosti, již je pro něj možné s druhým zapříst. Proto Františka, jejíž sebereflektivní vývoj napříč celou novelou dospěl do bodu, kdy si uvědomuje skutečnou hodnotu samostatnosti, tzn. svobodu, podotýká, že pro ni láska není pouhou každodenní stereotypností danou existenční mechaničností, jakou zažívala v rámci „štěstí“, jímž byla naplněna její partnerská vzájemnost s Petrem. Láska je pro ni již něčím více: „Ve skutečnosti bych nikdy nemohla milovat nikoho, ke komu nepocítím nejdříve přátelství. “22 Františka se do Gerberta zamilovala, protože si uvědomila, že jeho existence je svobodná, samostatná, k čemuž dospěla díky svému postupnému vzdalování se Petrovi a tím i osamostatňování se. 
Existence, které je vlastní svoboda, je charakteristická reciprocitou, protože oba aspekty, které jsme výše na svobodě identifikovali, vyjadřují respekt vůči sobě stejně jako vůči druhému. Tak i přátelství, jako nejryzejší výraz takto chápané svobody, umožňuje zachovat si identitu dokonce i v lásce, jelikož ta již není masochistickou či sadistickou partnerskou vzájemností, nýbrž vzájemností ohleduplnou a podporující, s uchováním vlastní samostatnosti: „Gerbert nikdy nezakotví, nebude patřit nikdy nikomu. A dával jí bez výhrad všechno, co mohl dát.“23

\section{Závěr}

Svoboda, již jsme chtěli na prvním publikovaném díle Simone de Beauvoir vyzdvihnout, se ukázala být svobodou bytostně spjatou s určitým způsobem existence - způsobem, jehož primárním charakterem je konstantní proměnlivost, znemožňující jakýkoli existenční způsob vztahu k druhému jakožto k někomu na mne navázanému nebo mne zavazujícímu. Naopak, svoboda se v Pozvané ukazuje být svobodou bytí jak pro sebe, tak pro druhé. Podobně jak to ukázal vztah Františky s Gerbertem, uvědomění si vlastní existenční svobody je podmíněné pouze pochopením vlastní schopnosti samostatně existovat prostřednictvím oproštění se od svazujících pout jistoty každodennosti. Teprve díky tomu si člověk může plně uvědomit podobu vlastní situovanosti a možnosti jejího budoucího rozvíjení - rozvíjení, které se bude uskutečňovat ve spolupráci s druhými.

\section{Mgr. et Mgr. Daniel Štěpánek}

Katedra filozofie, Filozofická fakulta, Masarykova univerzita

Arna Nováka 1, 60200 Brno

Česká republika

danielstepanek89@gmail.com

23 Tamtéž, s. 378. 